\title{
EKSISTENSI PAJAK BAGI PEMBANGUNAN NASIONAL
}

\author{
Zakka Pranggapati Janges dan Ilham Aji Pangestu \\ Fakultas Hukum, Universitas Sebelas Maret dan Fakultas Hukum, Universitas Islam Syekh-Yusuf \\ zakkapranggapati@gmail.com \& iapangestu@unis.ac.id
}

\section{Abstract}

Taxes are mandatory contributions imposed on the public coercively by state without direct reciprocal obtained from the tax payment. The main purpose of such is as state revenue for national development which aims to improve the welfare of its people and is collected based on the principle of justice. This can be observed from 3 perspectives, which is philosophical, juridical, and sociological perspectives. Philosophically, tax collection is fair because it is desired and approved by the public through DPR as the people's representative who creates law on tax collection. Moreover, the collected taxes are also for national development in order to achieve welfare state. Juridically, the government has made efforys to improve tax regulations to keep up with the times and society since the early days of independence, such as UU KUP that has beed revised several times from 1983 to 2009. In addition, the issued tax regulations also prioritize elements of justice such as PPh which in calculation uses progressive rates and PTKP. Sociologically, public awareness is still lacking. This can be solved by government efforts to create good image of tax by implementing the principles of good governance in order to create social trust and the people themselves want to pay taxes (voluntary tax compliance).

\section{Keywords: Tax, National Development, Principle of Justice, Welfare State}

\section{Abstrak}

Pajak merupakan iuran wajib yang dikenakan kepada masyarakat oleh negara yang bersifat memaksa dan tidak ada timbal balik kepada masyarakat secara langsung yang didapatkan dari pembayaran pajak tersebut. Tujuan utama pemungutan pajak yaitu sebagai pendapatan negara guna pembangunan negara yang bertujuan untuk menyejahterakan rakyatnya dan dipungut berdasarkan asas keadilan. Hal ini dapat dilihat dari 3 perspektif yaitu perspektif filosofis, yuridis, dan sosiologis. Secara filosofis pemungutan pajak adil karena dikehendaki dan disetujui oleh masyarakat melalui DPR sebagai perwakilan rakyat yang menciptakan undang-undang mengenai pemungutan pajak sehingga kedaulatan rakyat tetap diagungkan. Selain itu pajak yang dipungut juga untuk pembangunan nasional agar terciptanya welfare state. Secara yuridis, pemerintah telah berupaya memperbarui peraturan perpajakan untuk mengikuti perkembangan zaman dan masyarakat sejak awal masa kemerdekaan, seperti UU KUP yang telah berubah beberapa kali sejak tahun 1983 sampai terakhir 2009. Selain itu peraturan perpajakan yang dikeluarkan pemerintah juga mengutamakan unsur keadilan seperti PPh yang dalam perhitungannya menggunakan tarif progresif dan mengenal adanya PTKP. Secara sosiologis, kesadaran membayar pajak di dalam masyarakat masih kurang. Hal ini dapat diatasi dengan upaya pemerintah mewujudkan good image of tax dengan menjalankan prinsip good governance agar terciptanya social trust dan masyarakat dengan sendirinya ingin membayar pajak (voluntary tax compliance).

\section{Kata kunci : Pajak; Pembangunan Negara; Asas Keadilan; Welfare State}




\section{A. Pendahuluan}

Pajak merupakan iuran wajib yang dikenakan kepada masyarakat oleh negara yang bersifat memaksa dan tidak ada timbal balik kepada masyarakat secara langsung yang didapatkan dari pembayaran pajak tersebut. Eksistensi pajak sudah ada sejak awal peradaban manusia dan terus berkembang seiring berkembangnya zaman, masyarakat, dan keadaan ekonomi daerah tertentu. Bentuk pajak dan tata cara pemungutannya juga berbedabeda. Namun tujuan utama pemungutan pajak yaitu sebagai pendapatan negara guna pembangunan negara yang bertujuan untuk menyejahterakan rakyatnya.

Pajak sudah ada kurang lebih sejak abad ke-20 Sebelum Masehi (2000 SM sampai dengan 1900 SM) di Mesopotamia Kuno yang dikenal dengan sebutan miksu atau makasu atau biltu yang ditarik oleh pejabat kerajaan. Pajak di kala itu pada dasarnya dikenakan di sektor komersial dan sektor agraria, seperti kepada tuan tanah, petani, dan juga pebisnis, serta dibebankan pula kepada angkatan kerja negara (mereka yang bekerja bagi pemerintah), tentara, gembala ternak, dan juga tukang perahu atau pedayung perahu yang transit di suatu daerah. Bentuk pembayaran miksu tersebut juga bervariasi tergantung sektor apa yang dikenai, bisa berupa hasil pertanian, batu-batu mulia, hewan ternak. ${ }^{1}$ Pada tahun 200 Sebelum Masehi sampai dengan 400 Masehi Kerajaan Romawi membebankan pajak bagi warganya di semua daerah yang dikuasainya. Pengenaan pajak ini secara signifikan meningkatkan intensitas perdagangan dan produksi di seluruh kerajaan, baik inter-regional maupun intra-

\footnotetext{
${ }^{1}$ Maria deJ. Ellis, "Taxation in Ancient Mesopotamia: The History of the Term Miksu." Journal of Cuneiform Studies, vol. 26, no. 4, 1974, pp. 211-250, doi:

$10.2307 / 1359443$.
}

regional. ${ }^{2}$ Pajak ini lalu disalurkan ke daerahdaerah yang mengonsumsi pajak seperti di lingkaran luar perbatasan provinsi di mana banyak tentara berjaga, lingkaran dalam seperti Spanyol, Afrika bagian utara, sebagian kecil daerah Asia, Siria, dan Mesir, dan juga pusat yaitu daerah Italia dan Kota Roma. Secara garis besar daerah penyumbang pajak (tax-exporting province) menyalurkan pajak mereka ke daerah yang mengonsumsi pajak (tax-importing province). ${ }^{3}$

Di Indonesia sendiri konsep pajak sudah dikenal sejak zaman kerajaan, yaitu pemberian upeti rakyat kepada Raja dimana upeti tersebut dimanfaatkan untuk pembiayaan membuat saluran irigasi, keamanan, memelihara jalan, dan pembangunan sosial lainnya. ${ }^{4} \mathrm{Di}$ masa kependudukan Belanda Vereenigde Oostindische Compagnie (VOC) juga membebankan pajak, diantaranya pajak rumah, pajak usaha, dan pajak-pajak lain yang dikenakan kepada para pedagang. Di masa kependudukan Inggris, salah satu pajak yang dibebankan kepada rakyat dikenal dengan sebutan land rent atau sewa tanah yang meniru sistem pengenaan pajak di India. Dalam Undang-pasca kemerdekaan, Undang Dasar 1945 pajak diatur dalam Bab VIII Pasal 23 Ayat (2) Tentang Hal Keuangan yang menyatakan bahwa Segala pajak untuk keperluan negara berdasarkan UU. Hukum yang mengatur pajak terus berkembang. Pajak yang sebelumnya diatur di dalam Pasal 23 Ayat (2) sekarang diatur di dalam Pasal 23 A yang menyatakan bahwa Pajak dan pungutan lain yang bersifat memaksa untuk keperluan negara diatur dengan undang-undang. Ketentuan umum dan tata cara perpajakan terbaru sekarang dimuat di dalam UU No. 16 Tahun

\footnotetext{
${ }^{2}$ Keith Hopkins, "Taxes and Trade in the Roman Empire (200 B.C.-A.D. 400)." The Journal of Roman Studies, vol. 70, 1980, pp. 101-125, doi: 10.2307/299558.

${ }^{3}$ Ibid, 101.

${ }^{4}$ Wirawan B. Ilyas dan Richard Burton, Hukum Pajak: Teori, Analisis, dan Perkembangannya, Edisi 6, (Jakarta: Salemba Empat, 2010)
} 
2009 tentang Ketentuan Umum dan Tata Cara Perpajakan dan pengertian pajak diatur di dalam Pasal 1 Angka 1 yang berbunyi Pajak adalah kontribusi Wajib Pajak kepada negara yang terutang oleh Orang Pribadi atau badan yang bersifat memaksa berdasarkan undangundang dengan tidak mendapatkan imbalan secara langsung dan digunakan untuk keperluan negara bagi sebesar-besarnya kemakmuran rakyat.

Pajak yang dikenakan sejak zaman Mesopotamia Kuno sampai era modern ini tentunya memiliki tujuan, salah satunya yaitu sebagai sumber income negara yang hasilnya digunakan untuk menambah kas negara dan akan digunakan untuk membiayai segala pengeluaran negara seperti membangun saluran irigasi, membangun jalan, membayar tentara dan pekerja-pekerja pemerintah, bahkan sebagai insentif untuk mendorong kelancaran pasar yang akan memengaruhi keadaan ekonomi negara tersebut. Pajak dipungut demi pembangunan nasional dalam rangka mensejahterakan rakyatnya.

Dalam praktiknya, pajak yang dipungut seharusnya memenuhi asaskeadilan (equality) sesuai dengan ajaran Adam Smith mengenai asas pemungutan pajak yang dikenal sebagai The Four Maxims. Pemungutan pajak berdasarkan asas keadilan yaitu pajak yang dikenakan harus sesuai dengan kemampuan membayar pajak (ability to pay) dan penghasilan setiap wajib pajak. ${ }^{5}$ Di Indonesia, pajak yang dipungut juga seharusnya memenuhi asas keadilan ini. Untuk itu, maka penulis akan menelaah perpajakan di Indonesia melihat dari perspektif filosofis, yuridis, dan sosiologis.

Penelitian ini disusun untuk mengetahui pentingnya pajak bagi pembangunan nasional dan apakah pemungutan pajak di Indonesia sudah memenuhi asas keadilan dilihat dari

\footnotetext{
${ }^{5}$ Adam Smith and Edwin Cannan,The Wealth of Nations, (New York, N.Y: Bantam Classic, 2003)
}

berbagai perspektif untuk mencapai welfare state.

\section{B. Metode Penelitian}

Penelitian ini menggunakan metode deskriptif dengan menjelaskan mengenai perpajakan dari berbagai perspektif yang telah terjadi dari masa lampau sampai masa sekarang. Pengumpulan data penelitian ini dilakukan melalui studi kepustakaan dari data sekunder baik peraturan perundang-undangan, buku maupun serta jurnal-jurnal yang terkait dengan pembahasan.

\section{Hasil dan Pembahasan}

\section{Filosofis}

Setiap negara berdaulat pasti memerlukan sumber pendapatan yang stabil untuk membiayai segala pengeluaran negara. Salah satu sumber pendapatan negara utama dan terbesar Indonesia adalah pajak. ${ }^{6}$ Semua sumbersumber pendapatan negara dapat juga dikatakan sebagai keuangan negara. Keuangan negara dalam arti luas meliputi Anggaran Pendapatan dan Belanja Negara (APBN), Anggaran Pendapatan dan Belanja Daerah (APBD), keuangan negara pada Perusahaan Jawatan (Perjan), Perusahaan Umum (Perum), dan lain sebagainya. Sedangkan pengertian keuangan negara dalam arti sempit yaitu hanya meliputi badan hukum yang berwenang mengelola dan mempertanggung-jawabkannya. Semua yang telah disebutkan di atas merupakan sumber-sumber yang mengisi APBN Indonesia. Keuangan negara menjadi urat nadi pembangunan suatu negara dan sangat menentukan keberlangsungan perekonomian negara,

\footnotetext{
${ }^{6}$ Roristua Pandiangan, Hukum Pajak, (Yogyakarta: Graha Ilmu, 2015)
} 
baik di masa sekarang maupun masa yang akan datang. ${ }^{7}$

UU Nomor 17 Tahun 2003 mendefinisikan tentang keuangan negara sebagai “..semua hak dan kewajiban negara yang dapat dinilai dengan uang, serta segala sesuatu baik berupa uang maupun barang yang dapat dijadikan milik Negara berhubung dengan pelaksanaan hak dan kewajiban tersebut. "8 Undang-Undang ini tentunya lahir dari perkembangan hukum yang telah diatur sebelumnya namun masih sangat mendasar, yaitu UUD Tahun 1945. Pengaturan keuangan negara dalam UUD Tahun 1945 diatur dalam satu pasal yang sangat singkat, yaitu di dalam Bab VIII Pasal 23 tentang Hal Keuangan. Rumusan singkat ini dapat dipahami karena suasana kebatinan negara pada saat itu menginginkan segera terbentuknya Negara Republik Indonesia. ${ }^{9}$ Di dalam pasal tersebut, konsepsi keuangan negara memberikan pemahaman filosofis terhadap kedudukan keuangan negara yang ditentukan APBN sebagai bentuk penjelmaan kedaulatan. Dengan kata lain, hakikat public revenue (pendapatan) dan expenditure (pengeluaran) keuangan negara dalam APBN merupakan kedaulatan. Filosofi tersebut selaras dengan pandangan Rene Stourm yang menyatakan The constitutional right which a nation possesses to authorize public revenue and expenditures does not originates from the fact that the members of the nation contribute the payments. This right is based on a loftier idea. The idea of sovereignity. ${ }^{10}$

\footnotetext{
${ }^{7}$ Adrian Sutedi, Hukum Keuangan Negara, (Jakarta: Sinar Grafika, 2010)

${ }^{8}$ Tertuang di dalam Bab 1 Ketentuan Umum Pasal 1 Angka 1 Undang-Undang Nomor 17 Tahun 2003

Tentang Keuangan Negara.

${ }^{9}$ Sutedi, Keuangan Negara, 13.

${ }^{10}$ Kutipan ini dikemukakan oleh Rene Stourm dalam bukunya Cours de Finance : Le Budget, sebagaimana dikutip oleh Vincent J. Browne dalam bukunya The Control of Public Budget.
}

Pasal 23 Ayat (1) UUD Tahun 1945 menyatakan APBN ditetapkan tiap-tiap tahun dengan UU dan apabila DPR tidak menyetujui anggaran usulan pemerintah, pemerintah menjalankan anggaran tahun yang lalu. Pasal diatas menunjukan adanya hak begrooting DPR, yang menyatakan bahwa kedudukan DPR lebih tinggi daripada pemerintah dalam hal menetapkan pendapatan dan belanja negara.

Seperti yang kita ketahui Indonesia merupakan negara demokrasi, dimana kekuasaan tertinggi dan kedaulatan ada di tangan rakyat. ${ }^{11}$ Dari uraian di atas, menurut konsepsi hukum keuangan negara, pada hakikatnya APBN adalah kedaulatan yang diberikan oleh DPR. Bukti bahwa pemegang kedaulatan adalah rakyat melalui DPR adalah pemerintah hanya dapat menjalankan APBN setelah mendapat persetujuan DPR dalam bentuk UU, dan persetujuan DPR terhadap APBN yang diajukan oleh pemerintah ini merupakan kuasa (matchiging). 12

APBN sendiri memiliki sumber-sumber pendapatan sebagaimana yang telah disebutkan di atas. Sumber pendapatan yang berkontribusi terbesar atas seluruh APBN merupakan pajak. Penerimaan perpajakan Indonesia di tahun 2019 ini sebesar 1.768,4 T (rupiah) dan angka ini selalu naik setiap tahunnya. Dibandingkan dengan penerimaan APBN yang lain seperti Penerimaan Negara Bukan Pajak dan hibah yang tahun ini diterima masing-masing sebesar 378,3 T dan 0,4 T, sehingga dapat disimpulkan bahwa pajak merupakan sumber revenue negara yang paling besar dan reliable untuk Indonesia saat ini. ${ }^{13}$ Maka dari itu, eksistensi pajak sangat penting sebagai sumber

\footnotetext{
${ }^{11}$ Lihat UUD 1945 Bab 1 Bentuk dan Kedaulatan Pasal 1 Ayat (2).

12 Sutedi, Keuangan Negara, 14-15

${ }^{13}$ Data Kementerian Keuangan menunjukan bahwa paling tidak sejak tahun 2015 penerimaan pajak selalu naik. Penerimaan pajak sejak tahun 2015 sampai dengan 2018 yaitu sekitar $1.240,1.285,1.472$, dan 1.618 triliun rupiah.
} 
pendapatan negara dan pungutannya pun dilakukan dengan consent dan kedaulatan penuh oleh rakyat melalui Dewan Perwakilan Rakyat.

Dalam perpajakan, para wajib pajak tidak akan mendapat imbalan langsung atau kontraprestasi atas kontribusi mereka, melainkan penerimaan hasil pajak akan dikumpulkan dan dialokasikan untuk pembiayaan kepentingan umum dan demi kesejahteraan rakyat guna melaksanakan pembangunan nasional. ${ }^{14}$ Pajak dipungut bukan untuk special benefit.Kriteria inilah yang membedakan pajak dengan pungutan lain seperti misalnya retribusi. Retribusi di lain sisi dipungut dari mereka yang hendak mengonsumsi barang dan/atau jasa tertentu. Mereka yang membayar retribusi tersebut akan memperoleh manfaat langsung dari pembayaran yang dilakukan. Contoh seseorang dapat menikmati penggunaan listrik dan air apabila telah membayar retribusi atas kedua hal tersebut.

Pajak merupakan salah satu instrumen negara untuk menjalankan fungsinya, seperti misalnya untuk pengadaan public goods serta fungsi-fungsi lain seperti alokasi, distribusi, dan stabilisasi. Public goods ini akan dapat dinikmati oleh masyarakat. Fungsi alokasi yang dimaksud ialah tindakan pemerintah untuk mengalokasikan dana dalam rangka mengadakan barang dan jasa ketika pasar tidak dapat atau tidak mau memproduksi suatu barang/ jasa yang dibutuhkan masyarakat luas akibat market failure. Market failure ini terjadi disebabkan oleh pasar yang menilai bahwa produksi suatu barang atau jasa tidaklah efisien. Karena itulah keberadaan pemerintah dalam alokasi dana untuk pengadaan barang dan jasa sangat diperlukan. Pemerintah juga bertanggung jawab mendistribusikan pendapatan agar kesejahteraan dapat menyebar secara rata keseluruh lapisan masyarakat, dan melalui pajak, negara

\footnotetext{
${ }^{14}$ Sesuai dengan harapan Indonesia sebagai welfare state yang tercermin di UUD NRI 1945.
}

dapat melakukan pemerataan seperti misalnya layanan kesehatan yang terjangkau serta subsidi pada bahan-bahan pokok. Fungsi stabilitas dilakukan pemerintah dengan menggunakan kebijakan anggaran sebagai instrumen untuk menangani macro economic problems seperti tingkat ketenagakerjaan, stabilitas harga, dan pertumbuhan ekonomi. Ketiga fungsi yang telah disebutkan memerlukan pembiayaan yang tidak sedikit, dan pajak merupakan sumber pendapatan utama dan terbesar Indonesia. Pelaksanaan fungsi-fungsi pemerintahan diatas didanai oleh pajak memiliki kelebihan dibandingkan alternatif lain seperti cetak uang (money printing), pinjaman baik luar negeri dan dalam negeri, serta menjual cadangan devisa (running down foreign exchange reverses).

Dilihat dari alternatif diatas dapat dikatakan bahwa pajak merupakan satu-satunya penerimaan negara yang aman, murah, dan berkelanjutan. Aman berarti dapat terhindar dari intervensi negara lain atau Lembaga Pemberi Pinjaman, sedangkan murah yaitu tidak terbebani dengan bunga pinjaman maupun obligasi. Apabila negara meminjam uang kepada luar negeri tentunya akan dikenakan bunga dalam pengembaliannya. Meminjam ke luar negeri juga sebenarnya "menggeser atau memindahkan" pajak yang seharusnya terutang saat ini (present tax) menjadi pajak di masa yang akan datang (future tax). Penerbitan obligasi untuk melakukan peminjaman dalam negeri juga dibebani bunga dalam pengembaliannya kepada pembeli obligasi. Selain itu obligasi yang berlebihan dan tidak dikelola dengan baik akan menyebabkan crowd out atau sesaknya pasar yang pada akhirnya tingkat suku bunga meningkat. Berkelanjutan menggambarkan sumber-sumber pemungutan pajak terdapat disetiap aktivitas masyarakat, artinya selama pemerintah memberikan jaminan keamanan dan mendorong kegiatan perekonomian dimasyarakat maka akan selalu ada sumber penerimaan untuk negara. 
Secara filosofi keadilan pemungutan pajak di Indonesia dapat dilihat dari salah satu fungsi pajak itu sendiri yaitu fungsi penerimaan atau budgetair. Fungsi pajak sebagai penerimaan negara berarti pajak digunakan untuk membiayai segala pengeluaran negara, baik seperti pengeluaran untuk belanja pegawai, maupun pengeluaran untuk pembangunan. ${ }^{15}$ Karena pada hakikatnya pajak dipungut untuk pembangunan nasional, yang berarti semua lapisan masyarakat akan dapat menikmati hasil dari pembangunan tersebut, maka pemungutan pajak yang dilakukan sudah memenuhi unsur keadilan. Pajak yang dipungut oleh pemerintah juga sudah mengedepankan kedaulatan rakyat karena untuk memungut pajak guna mengisi APBN diperlukan hukum yang mengaturnya yaitu undang-undang.Dengan diberlakukannya suatu undang-undang yang mengatur tentang pemungutan pajak maka itulah cerminan dari kehendak rakyat melalui wakilnya yaitu DPR.

\section{Yuridis}

Hukum yang mengatur tentang perpajakan di Indonesia sangatlah beragam, mulai dari zaman pendudukan VOC sampai era reformasi sekarang ini. Di Indonesia sendiri konsep pajak sudah dikenal sejak zaman kerajaan. Rakyat memberikan upeti wajib kepada raja atau penguasa dalam berbagai bentuk seperti hasil pertanian atau hewan-hewan ternak. Pada awalnya upeti yang diberikan berbeda dengan pajak yang kita ketahui saat ini, yaitu para pemberi upeti tidak mendapat imbalan apapun baik secara langsung maupun tidak langsung. Hal ini dikarenakan upeti yang dibayarkan semata-mata karena raja atau penguasa merupakan sosok yang kedudukan sosialnya lebih tinggi dan rakyat biasa yang kedudukan sosialnya lebih rendah secara etis wajib membayar. Seiring berjalannya waktu, upeti berasal dari rakyat digunakan untuk kepenting-

\footnotetext{
${ }^{15}$ Siti Resmi, Perpajakan: Teori dan Kasus, edisi 8 (Jakarta: Penerbit Salemba Empat, 2014)
}

an umum dan tidak hanya untuk kepentingan raja atau penguasa saja. Upeti tersebut dimanfaatkan untuk pembiayaan membuat saluran irigasi, keamanan, memelihara jalan, dan pembangunan sosial lainnya. ${ }^{16}$ Konsep keadilan dari upeti ini pun muncul, yaitu uang, atau barang-barang yang lazim digunakan untuk upeti atau alat pembayaran, digunakan untuk pembiayaan apapun kebutuhan rakyat di sana sehingga uang tersebut pada akhirnya akan kembali lagi. Lebih dalam lagi, rakyat juga mulai diikutsertakan dalam membuat aturan atau hukum tentang upeti sehingga unsur keadilan pun semakin dijunjung.

Pada tahun 1603, kongsi dagang Belanda, VOC mendarat di Banten untuk kedua kalinya sejak diusirnya ekspedisi pertama Belanda pada tahun 1596 di bawah pimpinan Cournelis de Houtman. VOC dibentuk oleh pemerintahan Belanda untuk menjadi payung bagi pedagangpedagang Belanda dan untuk bersaing dengan kongsi-kongsi dagang negara-negara Eropa lainnya.VOC dapat dikatakan istimewa karena hak yang diberikan oleh pemerintah Belanda yaitu hak oktrooi dimana VOC sudah bak negara sendiri.

Hak oktrooi ini memungkinkan VOC untuk memungut pajak. Pajak yang dipungut oleh VOC salah satunya adalah contingenten dan preanger stelsel. Contingenten merupakan kewajiban rakyat untuk membayar pajak hasil bumi, sedangkan preanger stelsel merupakan bentuk pajak dimana rakyat wajib membayar pajak bukan berbentuk uang namun berbentuk hasil bumi yang nilainya sama dengan pajak yang dikenakan. Semenjak itu muncul berbagai macam pajak seperti pajak rumah, pajak usaha, dan pajak-pajak lain yang dikenakan kepada para pedagang.

Pada masa kemerdekaan, Indonesia sudah memiliki pandangan akan keuangan

\footnotetext{
${ }^{16}$ Wirawan B. Ilyas dan Richard Burton, Hukum Pajak: Teori, Analisis, dan Perkembangannya, Edisi 6, (Jakarta: Salemba Empat, 2010)
} 
negara guna pembangunan nasional yang dituangkan di dalam UUD 1945 Bab VIII Pasal 23 tentang Hal Keuangan. Ayat pertama dari pasal tersebut menyatakan bahwa Anggaran pendapatan dan belanja ditetapkan tiap-tiap tahun dengan undang-undang. apabila Dewan Perwakilan Rakyat tidak menyetujui anggaran yang diusulkan pemerintah, maka pemerintah menjalankan anggaran tahun yang lalu. Lalu pada ayat kedua menyatakan bahwa segala pajak untuk keperluan negara dipungut berdasarkan undang-undang. ${ }^{17}$ APBN dan pemungutan pajak dapat dilakukan karena adanya consent dan kehendak dari masyarakat Indonesia. Hal ini dapat kita lihat dari pasal di atas bahwa APBN dan pemungutan pajak ditetapkan berdasarkan undang-undang. Undang-undang dibuat oleh Dewan Perwakilan Rakyat sebagai badan legislatif Indonesia dan dengan ini pemungutan pajak telah mendapat persetujuan dari rakyat melalui wakilnya di DPR. Hal ini biasa disebut "berasaskan yuridis". ${ }^{18}$ Pasca amandemen pasal yang mengatur APBN dan pajak pun tidak menghilangkan esensinya yaitu diadakan berdasarkan undang-undang. Pentingnya landasaln hukum atas pemungutan pajak adalah untuk kepastian hukum dan jaminan hukum akan hak negara memungut pajak sebab pungutan pajak tanpa undang-undang (hukum) merupakan perampokan (taxation without representation is a robbery). ${ }^{19}$ Pasal 23 tentang Hal Keuangan sekarang dipecah menjadi pasal 23, 23A, 23B, 23C, dan 23D.Mekanisme disusunnya APBN sekarang dijelaskan dengan lebih rinci.

Setelah Indonesia merdeka pajak yang dikenakan sebenarnya masih mengikuti pajak yang sebelumnya dipungut oleh Belanda. Berdasarkan peraturan peralihan UUD 1945, Indonesia memberlakukan Ordonansi Pajak Pendapatan 1932 yang merupakan produk

\footnotetext{
${ }^{17}$ Undang-Undang Dasar 1945 sebelum amandemen.

${ }^{18}$ Ilyas dan Burton, Hukum Pajak, 5.

${ }^{19}$ Ibid, 7.
}

hukum Belanda. Ordonansi ini lalu diubah namanya menjadi Pajak Perang. Untuk pajak penghasilan sendiri sudah mengalami banyak perubahan, dimana pada awalnya berawal dari Ordonansi Pajak Pendapatan dan Ordonansi Pajak Perseroan. Pajak-pajak lain yang menjadi cikal bakal perpajakan masa kini yaitu Ordonansi Rumah Tangga (Stbl. 1908 No. 13), Ordonansi Pajak Kekayaan (Stbl. 1932 No. 405), dan Ordonansi Pajak Upah (Stbl. 1934 No. 611). Seiring berkembangnya masyarakat dan keadaan ekonomi, maka diundangkan lagi beberapa ketentuan perundangan seperti Undang-undang Pajak Penjualan Tahun 1951; Undang-undang No. 10 Tahun 1967 Tentang Pajak atas Bunga, Dividen, dan Royalti; dan Undang-undang No. 8 Tahun 1967 Tentang Tata Cara Pemungutan Pajak Pendapatan, Pajak Kekayaan, dan Pajak Perseroan atau Tata Cara MPS-MPO.

Karena pajak yang diberlakukan Belanda sendiri sudah banyak dan Indonesia pada saat itu masih memberlakukan peraturan peralihan, hal ini menyebabkan masyarakat menjadi kesulitan dalam pelaksanaannya. Selain itu, dalam perkembangannya, beberapa peraturan tersebut ternyata tidak memenuhi rasa keadilan karena dirasa masih dibuat oleh dan untuk kepentingan Belanda. ${ }^{20}$ Menyadari keadaan yang demikian, pemerintah bersama dengan legislatif sepakat melakukan reformasi peraturan perpajakan dengan mencabut semua UU yang ada dan mengundangkan lima (5) paket UU perpajakan yang lebih mudah dipelajari dan dipraktikkan dan tidak menimbulkan duplikasi dalam hal pemungutan pajak serta lebih mengutamakan unsur keadilan di dalamnya. Bahkan sistem perpajakan yang semula menggunakan sistem official assessment dirubah menjadi sistem yang bersifat self assessment. Kelima peraturan tersebut tersebut adalah Undang-undang No. 6 Tahun 1983 tentang Ketentuan Umum dan Tata Cara Per-

${ }^{20}$ Ibid, 2. 
pajakan, Undang-undang No. 7 Tahun 1983 tentang Pajak Penghasilan (PPh), Undangundang No. 8 Tahun 1983 tentang Pajak Pertambahan Nilai atas Barang dan Jasa dan Pajak Penjualan atas Barang Mewah (PPN dan PPnBM), Undang-undang No. 12 Tahun 1983 tentang Pajak Bumi dan Bangunan (PBB), dan Undang-undang No. 13 Tahun 1983 tentang Bea Materai (BM). ${ }^{21}$

Official assessment system merupakan sistem pemungutan pajak yang memberi kewenangan kepada aparatur perpajakan untuk menentukan jumlah pajak yang terutang setiap tahunnya sesuai dengan peraturan perundangundangan yang berlaku, dimana inisiatif serta kegiatan menghitung dan memungut pajak sepenuhnya berada di tangan para aparatur perpajakan. Di sisi lain, self assessment system merupakan sistem pemungutan pajak yang memberikan wewenang Wajib Pajak dalam menentukan sendiri jumlah pajak yang terutang setiap tahunnya sesuai dengan peraturan perundang-undangan yang berlaku, dimana inisiatif serta kegiatan menghitung pajak juga pembayaran pajak sepenuhnya berada di tangan Wajib Pajak. ${ }^{22}$

Dengan pemberlakuan paket peraturan tersebut, diharapkan masyarakat disemua lapisan untuk turut berpartisipasi dan dapat lebih memahami akan kewajibannya untuk membayar pajak sesuai dengan sistem self assessment yang berlaku sejak tahun 1983 berdasarkan reformasi undang-undang perpajakan tersebut.

Pada tahun 1997, pemerintah kembali melakukan perubahan atas undang-undang perpajakan dengan menyusun UU yang berkaitan dengan masalah perpajakan dalam rangka mendukung UU yang sudah ada, yaitu UU tentang Badan Penyelesaian Sengketa Pajak; Pajak Daerah dan Retribusi Daerah; Penagihan Pajak dengan Surat Paksa; Penerimaan Negara

\footnotetext{
${ }^{21}$ Ibid, 3.

${ }^{22}$ Resmi, Perpajakan, 11.
}

Bukan Pajak; dan Bea Perolehan Hak atas Tanah dan Bangunan. Peraturan perundangundangan terus mengalami perubahan seiring perkembangan ekonomi dan masyarakat dalam rangka memberikan rasa keadilan yang lebih baik dan meningkatkan pelayanan kepada Wajib Pajak.

Pada tahun 2007-2009 pemerintah kembali melakukan penyesuaian atas undangundang perpajakan. Perubahan UU KUP ditujukan dalam rangka lebih memberikan keadilan, kepastian hukum, dan meningkatkan pelayanan kepada Wajib Pajak serta mengikuti dan mengantisipasi perkembangan di bidang teknologi informasi. Undang-Undang Ketentuan Umum dan Tata Cara Perpajakan No. 16 Tahun 2000 diubah dengan UU No. 28 Tahun 2007, mulai berlaku 1 Januari 2008. Lalu UU KUP ini pun mengalami perubahan lagi dengan UU No. 16 Tahun 2009 tentang Penetapan Peraturan Pemerintah Pengganti UU No. 5 Tahun 2008 tentang Perubahan Keempat atas UU No. 6 Tahun 1983 tentang Ketentuan Umum dan Tata Cara Perpajakan. Dengan dilakukannya perubahan terhadap perangkat peraturan perundangan di bidang perpajakan menunjukan bahwa pemerintah selalu mengedapankan unsur keadilan dan memperhatikan stakeholder dalam melanjutkan pembangunan nasional yang menggunakan pajak sebagai sumber utamanya. $^{23}$

Setiap undang-undang perpajakan di Indonesia selalu berusaha untuk mengedepankan unsur keadilan bagi para Wajib Pajak.Hal ini dapat kita lihat dari pemungutan Pajak Penghasilan. Peraturan tentang pajak penghasilan sudah ada paling tidak sejak tahun 1983 yaitu UU No. 7 Tahun 1983 tentang Pajak Penghasilan. Selanjutnya peraturan tersebut mengalami perubahan beberapa kali hingga terakhir dirubah menjadi Undang-undang No. 36 Tahun 2008 Tentang Pajak Penghasilan (PPh).

\footnotetext{
${ }^{23}$ Ilyas dan Burton, Hukum Pajak, 3-5.
} 
Perhitungan pajak penghasilan juga dipengaruhi dengan Penghasilan Tidak Kena Pajak (PTKP). PTKP merupakan besarnya penghasilan yang menjadi batasan tidak kena pajak bagi Wajib Pajak Orang Pribadi. Menurut UU No. 7 Tahun 1983 PTKP per tahun diberikan paling sedikit sebesar Rp.15.840.000,00 untuk diri Wajib Pajak pribadi, Rp1.320.000,00 tambahan untuk Wajib Pajak yang kawin, Rp15.840.000,00 tambahan untuk seorang isteri yang penghasilannya digabung dengan suaminya; dan Rp1.320.000,00 tambahan untuk setiap anggota keluarga (maks. 3). ${ }^{24}$

Hal ini menandakan bahwa jumlah pajak penghasilan yang dipungut oleh pemerintah antara Wajib Pajak yang belum kawin dengan Wajib Pajak yang sudah kawin berbeda. Misal Si A dan Si B masing-masing berpenghasilan Rp360juta per tahun, sedangkan si B memiliki isteri yang tidak bekerja dengan 3 orang anak, maka pajak yang wajib dibayarkan oleh Si B per tahun sebesar Rp54.720.000,- sedangkan Si A harus membayar sebesar Rp56.040.000,-. Perbedaan ini tidak menyimpang dari asas keadilan yang dikemukakan Adam Smith dikarenakan Si B memiliki tanggungan hidup lebih besar daripada Si A karena Si B harus menafkahi 1 isteri dan 3 orang anak. Dapat disimpulkan juga bahwa ability to pay antara $\mathrm{Si}$ A dan Si B berbeda dimana ability to pay Si B lebih kecil daripada Si A dikarenakan uang penghasilan atau gaji untuk membayar pajak yang didapatkan Si B sudah "terpotong" untuk memenuhi kebutuhan keluarganya, sedangkan Si A hanya perlu menghidupi dirinya sendiri. Ketidaksamaan jumlah utang pajak belum tentu merupakan ketidakadilan karena kita harus melihat kemampuan membayar pajak tiap-tiap Wajib Pajak.

Perbedaan besarnya pajak sebenarnya dipengaruhi oleh tarif perpajakan yang diberlakukan suatu pemerintahan. Tarif juga me-

\footnotetext{
${ }^{24}$ Pasal 7 Ayat (1) UU No. 7 Tahun 2008.
}

rupakan salah satu unsur dalam menjaga keadilan perpajakan. Selama ini tarif yang berlaku dibedakan menjadi empat yaitu tarif tetap, tarif proporsonal, tarif degresif dan tarif progresif. Tarif tetap merupakan tariff pajak yang nominalnya tetap walapun dasar pengenaan pajaknya berbeda atau berubah, sehingga jumlah pajak yang terutang selalu tetap. Contoh dari tarif tetap ini adalah bea materai untuk cek dan bilyet giro yang dikenakan sebesar Rp1.000 berapapun nominal dasar pengenaan pajaknya. Yang kedua merupakan tarif proporsional atau sebanding, yaitu tarif dengan persentase yang tetap, tetapi jumlah pajak yang terutang akan berubah secara proporsional/sebanding dengan dasar pengenaan pajaknya. Contohnya yaitu pengenaan tarif PPN sebesar 10\%. Yang ketiga adalah tarif progresif dimana persentase tarif pajak akan semakin besar jika dasar pengenaan pajaknya meningkat. Di Indonesia, pemungutan $\mathrm{PPh}$ menggunakan tarif progresif dalam perhitungan di lapisan perhitungan pajak. ${ }^{25}$ Bentuk tarif yang terakhir ialah tarif degresif dimana, kebalikan dari tarif progresif, persentase tarif semakin menjadi semakin kecil jika dasar pengenaan pajaknya meningkat/bertambah. Tarif tarif ini tidak digunakan di Indonesia. ${ }^{26}$

\section{Sosiologis}

Pajak bertujuan untuk mensejahterakan masyarakat dengan digunakan untuk pengadaan barang dan jasa juga pembangunan infrastruktur. Namun, di dalam praktiknya masih banyak kendala yang ditemui, seperti wajib pajak yang enggan melaksanakan kewajibannya. Pemenuhan kewajiban sebagai Wajib Pajak didorong bermacam-macam. Jika seseorang membayar pajak karena didorong

\footnotetext{
${ }^{25}$ Lapisan perhitungan terbaru yaitu 5\% x Rp50juta, 15\% x Rp50juta s.d. Rp250juta, 25\% x Rp250juta s.d. Rp500juta, dan 30\% x diatas Rp500juta.

${ }^{26}$ Erly Suandy, Hukum Pajak, Edisi 6, (Jakarta: Salemba Empat, 2014)
} 
ketakutan akan mendapatkan sanksi, maka bentuk kepatuhan tersebut berasal dari keterpaksaan dan bukan karena kesadaran diri atau kesukarelaan. Kepatuhan didorong oleh rasa takut pada sanksi atau hukuman yang akan diberikan merupakan bentuk kepatuhan yang bersifat semu dan akan mengurangi manfaat dari penerapan sanksi. ${ }^{27}$ Sanksi baik pidana maupun administrasi sesungguhnya lebih kepada tujuan jangka pendek, yaitu dengan menghukum Wajib Pajak yang tidak melaksanakan kewajiban perpajakannya, daripada untuk mencapai tujuan jangka panjang yaitu mempengaruhi Wajib Pajak yang semula tidak kooperatif menjadi Wajib Pajak yang patuh. Karena itu implementasi Paksa Badan (gijzeling) yang ditetapkan dalam UU Penagihan Pajak dengan Surat Paksa(PPSP) tidak akan secara otomatis meningkatkan kepatuhan Wajib Pajak. Kebijakan gijzeling tidak akan berhasil dan hanya akan menjadi instrumen penagihan yang tumpul apabila tidak diikuti dengan peningkatan mutu layanan perpajakan, transparansi penggunaan pajak, penegakan hukum yang tidak diskriminatif, dan distribusi pemungutan pajak yang adil sehingga dapat mewujudkan peningkatan kesejahteraan masyarakat. ${ }^{28}$

Pemenuhan kewajiban pajak seharusnya murni dari kesadaran Wajib Pajak, bukan dari paksaan atau faktor luar apapun (voluntary tax compliance). Kepatuhan ini akan terwujud apabila fungsi-fungsi pemerintahan dilakukan dengan sungguh-sungguh sesuai prinsip dengan good governance. Kesadaran dan pemahaman pentingnya pajak serta adanya bukti positif yang ditunjukan oleh pemerintah, seperti dalam bentuk keamanan, tersedianya barang publik, pelayanan publik yang lebih baik, dan kesejahteraan rakyat yang merata akan menyadarkan

\footnotetext{
${ }^{27}$ Simon James and Christopher Nobes, The Economic of Taxation: Priciple, Policy, and Practice, 1996/1997 Edition, (Europe: Prentice Hall, 1996), 144.

${ }^{28}$ Haula Rosdiana dan Edi Irianto, Pengantar Ilmu Pajak: Kebijakan dan Implementasi di Indonesia, (Jakarta: Rajawali Pers, 2014). 19-20.
}

rakyat untuk lebih sadar akan urgensi untuk membayar pajak. $^{29}$

Dalam mewujudkan voluntary tax compliance dibutuhkan social trust yang tinggi terhadap pajak seiring dengan berkembangnya gambaran/ persepsi yang baik terhadap pajak (good image of tax). Peraturan perpajakan yang jelas,tegas, dan melindungi masyarakat juga transparansi penggunaan pajak oleh pemerintah merupakan salah satu hal yang perlu dikembangkan untuk mewujudkanlaw and order, social trust dangood image of tax sehingga masyarakat tahu untuk apa pajak dipungut, bagaimana pemerintah mengelola uang hasil pungutan pajak tersebut, dan apa yang diberikan kembali kepada masyarakat oleh pemerintah atas pemungutan pajak yang dilakukannya. Bila semua ini sudah terpenuhi maka pendapatan pajak (tax revenue) akan semakin meningkat. ${ }^{30}$

Sistem pemungutan pajak kita sebelum reformasi pajak ialah official assessment system dimana pemerintah melalui fiskus menghitung dan menentukan besaran pajak terutang Wajib Pajak. Berdasarkan surat ketetapan yang diterbitkan fiskus, wajib pajak membayar utang pajak tersebut.

Dalam sistem ini pemerintah memiliki kontrol yang lebih luas, namun sistem ini tidak mampu untuk mewujudkan voluntary tax compliance karena Wajib Pajak membayar pajak hanya karena diberi surat ketetapan dan tidak ada inisiasi dari Wajib Pajak itu sendiri untuk membayar pajak. Untuk melaksanakan negara dengan good governance pemerintah harus bekerja sama dan lebih melibatkan masyarakat akan pajak yang dikenakan. Oleh karena itu, pada reformasi perpajakan tahun 1985 sistem pemungutan Indonesia berubah

\footnotetext{
${ }^{29}$ Ibid.

${ }^{30}$ Merupakan gagasan perbaikan administrasi perpajakan dan upaya meningkatkan kepatuhan. Voluntary tax compliance untuk meningkatkan tax revenue baru akan berhasil bila sudah ada law and order, social trust, dan good image of tax.
} 
dari sistem official assessment menjadi sistem self assessment. Di dalam sistem self assessment, pemerintah memberikan kepercayaan kepada Wajib Pajak untuk menghitung, memperhitungkan, membayarkan, dan melaporkan besarnya pajak terutang sesuai jangka waktu yang telah ditentukan sebelumnya.Sistem ini merupakan upaya pemerintah guna mewujudkan social trust yang tercermin dari pemberian kepercayaan pemerintah kepada masyarakat agar tercipta good governance dan voluntary tax compliance.

Namun sistem ini memberikan permasalahan yang lain yaitu mudahnya wajib pajak dalam memanipulasi pajak terutang (tax evasion). Alasan terjadinya permasalahan ini yaitu satu, kurangnya pengetahuan wajib pajak dalam perhitungan pajaknya sendiri.Selain itu juga adanya tindakan tax evasion yang disengaja.Masih banyak wajib pajak yang terdaftar wajib Surat Pemberitahuan Tahunan (SPT) tidak melaporkan SPT-nya. SPT merupakan surat oleh wajib pajak untuk melaporkan perhitungan dan/atau pembayaran pajak, objek pajak, bukan objek pajak, dan/atau harta dan kewajiban. Jika SPT tidak dilaporkan maka penerimaan pajak juga akan berkurang karena yang seharusnya dibayarkan dan menjadi pendapatan negara malah tidak dilaporkan. Kemudahan akses informasis menjadi kendala utama dalam menjalankan self assessment dimana ada tiga unsur yang membentuk kendala akses informasi yaitu transparansi sistem perpajakan, ketidakpastian dan simplifikasi ketentuan perpajakan, serta sosialisasi dan edukasi wajib pajak. Hal tersebut menciptakan kompleksitas, varian, dan ambiguitas ketentuan perpajakan. Akibatnya, timbul ketidakseimbangan informasi yang menyulitkan wajib pajak melaksanakan kewajibannya dan memahami hak mereka. Karena itu sistem self assessment masih tidak dapat diimplementasikan dengan baik karena kesadaran masyarakat Indonesia sendiri yang masih rendah dan pemerintah yang kurang mendorong faktor- faktor terwujudnya self assessment yang ideal seperti transparansi perpajakan yang kurang.

Pajak dilimpahkan kepada masyarakat sebagai langkah bagi pemerintah untuk menjalankan good governance dan welfare state juga utiity theory. Good governance dimaksudkan dengan pemerintahan yang bersih, transparan kepada masyarakatnya dan menunjukan proses yang memposisikan rakyatnya untuk mengatur ekonominya dalam rangka pembangunan dan intergrasi penuh sehingga tercipta kesejahteraan bagi masyarakat. Social trust yang tinggi atas dasar good image of tax akan menumbuhkan voluntary tax compliance dimana masyarakat secara sukarela membayar pajak dan sadar penuh akan kebutuhan pajak juga manfaat yang diperoleh darinya. Welfare state mengemukakan bahwa negara bertanggung jawab untuk menyediakan kebutuhan masyarakat seperti fasilitas umum demi menunjang kesejahteraan masyarakat. Untuk membiayai pengadaan fasilitas umum ini diperlukan pajak sebagai pendapatan terbesar dan reliable bagi Indonesia saat ini. Sedangkan utility theory menyatakan bahwa pemanfaatan uang hasil pemungutan pajak harus diupayakan untuk pelayanan umum sebagai wujud pelayanan pemerintah kepada rakyatnya dan agar masyarakat dapat merasakan hasil dari pajak yang telah mereka bayar.

\section{Simpulan}

Pajak sangat penting bagi pembangunan suatu negara. Negara akan maju apabila pajak terus ditegakan dan, di lain sisi, negara akan mati bila pajak tidak ditegakan lagi. Di Indonesia pajak merupakan pendapatan negara terbesar dan terus berkembang dari tahun ke tahun.Sehingga penting agar pajak terus ditegakkan. Pemungutan pajak juga harus berdasarkan asas keadilan, dan keadilan pajak di Indonesia dapat dilihat dari 3 perspektif yaitu perspektif filosofi, yuridis, dan sosilologis. 
Secara filosofis pemungutan pajak sebagai penerimaan terbesar APBN itu adil karena dikehendaki dan disetujui oleh masyarakat. Pajak baru bisa dipungut apabila ada undangundang yang mengaturnya, sedangkan undangundang dibuat oleh DPR sebagai wakil rakyat sehingga kedaulatan rakyat tetap diagungkan. Selain itu pajak yang dipungut juga untuk pembangunan nasional agar terciptanya welfare state. Secara yuridis, pemerintah telah berupaya dalam memperbarui peraturan perpajakan untuk mengikuti perkembangan zaman dan masyarakat sejak awal masa kemerdekaan, seperti UU KUP yang telah berubah beberapa kali sejak tahun 1983 sampai terakhir 2009. Selain itu peraturan perpajakan yang dikeluarkan pemerintah juga mengutamakan unsur keadilan seperti $\mathrm{PPh}$ yang dalam perhitungannya menggunakan tarif progresif dan mengenal adanya PTKP. Secara sosiologis, kesadaran membayar pajak di dalam masyarakat masih kurang.Hal ini dapat diatasi dengan upaya pemerintah mewujudkan good image of tax dengan menjalankan prinsip good governance agar terciptanya social trust dan masyarakat dengan sendirinya ingin membayar pajak (voluntary tax compliance).

\section{DAFTAR PUSTAKA}

\section{Buku}

Ilyas, Wirawan B.,et al., 2010, Hukum Pajak: Teori, Analisis, dan Perkembangannya, Salemba Empat, Jakarta.

Rosdiana, Haula dan Irianto, Edi, 2014, Pengantar Ilmu Pajak: Kebijakan dan Implementasi di Indonesia, Rajawali Pers, Jakarta.

Suandy, Erly, 2014,Hukum Pajak, Salemba Empat, Jakarta.
Resmi, Siti, 2014, Perpajakan: Teori dan Kasus, Salemba Empat, Jakarta.

Sutedi, Adrian, 2010,Hukum Keuangan Negara, Sinar Grafika, Jakarta.

Pandiangan, Roristua, 2015,Hukum Pajak, Graha Ilmu, Yogyakarta.

\section{Artikel Jurnal}

Ellis, Maria deJ, "Taxation in Ancient Mesopotamia: The History of the Term Miksu." Journal of Cuneiform Studies, Vol. 26, No. 4, 1974, pp. 211-250, doi: 10.2307/1359443.

Hopkins, Keith, "Taxes and Trade in the Roman Empire (200 B.C.-A.D. 400)." The Journal of Roman Studies, Vol. 70, 1980, pp. 101-125, doi: $10.2307 / 299558$

\section{Peraturan Perundang-undangan}

Undang-Undang Dasar Negara Republik Indonesia Tahun 1945.

Undang-Undang Nomor 17 Tahun 2003 Tentang Keuangan Negara.

Undang-Undang Nomor 16 Tahun 2009 Tentang Ketentuan Umum dan Tata Cara Perpajakan 